\title{
Penyuluhan Manajemen Kesehatan, Reproduksi, Sanitasi Kandang, dan Pengobatan Massal Ternak Kambing
}

\author{
(Extension of Health Management, Reproduction, Pen Sanitation, \\ and Mass Medicine for Goats)
}

\author{
Muhammad Mirandy Pratama Sirat ${ }^{*}$, Madi Hartono, Purnama Edy Santosa², Ratna Ermawati², \\ Siswanto², Fani Setiawan², I Kadek Dwi Agus Candra Wijaya², Sherlina Widya Rahma², \\ Siti Tika Fatmawati² \\ ${ }^{1}$ Program Studi Nutrisi dan Teknologi Pakan Ternak, Jurusan Peternakan, Fakultas Pertanian, Universitas \\ Lampung, Jl. Soemantri Brodjonegoro No. 1 Gedong Meneng, Rajabasa, Bandar Lampung 35145. \\ 2 Program Studi Peternakan, Jurusan Peternakan, Fakultas Pertanian, Universitas Lampung, Jl. Soemantri \\ Brodjonegoro No. 1 Gedong Meneng, Rajabasa, Bandar Lampung 35145. \\ *Penulis Korespondensi: m.mirandy@fp.unila.ac.id
}

\begin{abstract}
ABSTRAK
Provinsi Lampung mempunyai peluang yang cukup strategis untuk pengembangan ternak ruminansia karena ketersediaan sumber daya alam yang mendukung. Salah satu jenis ternak ruminansia adalah kambing. Peternakan kambing rakyat pada saat ini sudah menyebar luas namun kondisi tatalaksana pemeliharaan belum optimal. Kendala yang masih sering dihadapi peternak kambing adalah kurangnya pengetahuan pada penanganan gangguan reproduksi dan kesehatan ternak, sanitasi kandang yang tidak sesuai dengan kondisi geografis daerah, serta minimnya bantuan pengobatan ternak yang diperoleh. Tim Pengabdian Kepada Masyarakat Skema Dosen Pemula BLU Universitas Lampung TA. 2020 melakukan penyuluhan manajemen kesehatan, reproduksi, dan sanitasi kandang serta pengobatan massal ternak kambing dengan tujuan pengabdian untuk meningkatkan pengetahuan dan cara pemeliharaan ternak rakyat konvensional menjadi berbasis ilmu pengetahuan. Sasaran kegiatan adalah peternak kambing di Desa Kota Agung, Kecamatan Sungkai, Kabupaten Lampung Utara. Metode kegiatan, yaitu 1) Penyuluhan manajemen kesehatan, reproduksi, dan sanitasi kandang ternak kambing; 2) Penerapan program sanitasi kandang dengan pembersihan dan desinfektasi kandang; dan 3) Pemeriksaan kesehatan dan pengobatan massal. Parameter pengukuran kegiatan untuk mengetahui respons peserta penyuluhan terhadap pelaksanaan kegiatan pengabdian dengan cara membandingkan perubahan nilai pada evaluasi awal (pre-test) dan evaluasi akhir (post-test). Hasil kegiatan pengabdian berupa 1) 31 orang peternak kambing mengikuti penyuluhan; 2) Pengobatan massal dilakukan pada 232 ekor kambing; dan 3) Sanitasi kandang pada 31 unit kandang. Hasil evaluasi kegiatan yaitu tingkat pengetahuan peternak pada sisi pengetahuan kesehatan kambing meningkat 54,02\%; sisi reproduksi meningkat 26,77\%; dan sisi pengetahuan sanitasi kandang meningkat 52,33\% setelah kegiatan dilaksanakan. Kesimpulan pengabdian ini bahwa keseluruhan kagiatan memberikan dampak positif yang sangat besar bagi peternak.
\end{abstract}

Kata kunci: kambing, pengobatan massal, penyuluhan, program kesehatan, sanitasi kandang

\begin{abstract}
Province of Lampung has a strategic opportunity for the development of ruminants because of the availability of natural resources that support it. One type of ruminant livestock is goat. People's goat farming is now widespread but the conditions of maintenance management are not optimal. Constraints that are still often faced by goat farmers are in terms of lack of knowledge on handling reproductive disorders and livestock health, cage sanitation that is not in accordance with regional geographical conditions and the lack of assistance for livestock treatment obtained. The Community Service Team Scheme Beginner Lecturers of BLU University of Lampung 2020 through counseling related to health management, reproduction and pen sanitation as well as mass treatment of goats were aims to increase knowledge and how to raise conventional people's livestock to be science-based. The target of the activity was goat breeders in Kota Agung Village, South Sungkai District, North Lampung Regency. Methods of activity, namely 1) Extension of health management, reproduction, and sanitation for goat sheds; 2) Implementing a pen sanitation program with cleaning and disinfection of the pen; and 3) Health checks and mass treatment. Activity measurement parameters to determine the response of extension participants to the implementation of community service activities by comparing changes in values in the initial evaluation (pre-test) and the final evaluation (post-test). Service activities were 1) 31 goat farmers was attending the counseling; 2) Mass treatment activities were carried out on 232 goats; and 3) Pen sanitation
\end{abstract}


activities were carried out at 31 goat pen with the results of the evaluation of activities, namely the level of breeders' knowledge on the goat health knowledge increased by $54.02 \%$; the reproductive knowledge increased by $26.77 \%$; and the pen sanitation knowledge increased by $52.33 \%$ after the activities were implemented. Conclusion of the overall activities had a very large positive impact on farmers.

Keywords: counseling, goats, health programs, mass treatment, pen sanitation

\section{PENDAHULUAN}

Provinsi Lampung mempunyai peluang yang cukup strategis untuk pengembangan ternak ruminansia karena ketersediaan sumber daya alam yang mendukung. Salah satu jenis ternak ruminansia adalah kambing. Peternakan kambing rakyat pada saat ini sudah menyebar luas namun kondisi tatalaksana pemeliharaan belum optimal. Kendala yang masih sering dihadapi peternak kambing adalah kurangnya pengetahuan pada penanganan gangguan reproduksi dan kesehatan ternak, model perkandangan yang tidak sesuai dengan kondisi geografis daerah, serta minimnya bantuan pengobatan ternak yang diperoleh. Sebagian besar peternak kambing masih memelihara secara tradisional tanpa memerhatikan aspek tatalaksana pemeliharaan, manajemen reproduksi, dan kesehatan serta pembuatan kandang yang memenuhi aspek sanitasi dan higienitas. Hal ini dikarenakan usaha peternakan kambing hanya menjadi usaha sampingan bukan menjadi mata pencaharian pokok bagi peternak yang juga memiliki mata pencaharian utama sebagai petani.

Desa Kota Agung, Kecamatan Sungkai Selatan, Kabupaten Lampung Utara merupakan salah satu desa yang masyarakatnya banyak memelihara kambing bibit maupun potong. Wilayah ini sangat mendukung untuk pengembangan populasi kambing karena potensinya yang mampu karena ketersediaan pakan ternak tinggi. Berdasarkan survei pendahuluan tampak bahwa pengetahuan dan wawasan peternak tentang manajemen kesehatan, reproduksi serta sanitasi kandang masih kurang sehingga produktivitas ternak kambing menjadi rendah, maka Tim Pengabdian Kepada Masyarakat Skema Dosen Pemula BLU Universitas Lampung TA. 2020 melakukan pembinaan melalui penyuluhan terkait manajemen reproduksi, kesehatan dan sanitasi kandang serta pengobatan massal ternak kambing dengan tujuan pengabdian untuk meningkatkan pengetahuan dan cara pemeliharaan ternak rakyat konvensional menjadi berbasis ilmu pengetahuan.

\section{METODE PELAKSANAAN KEGIATAN}

\section{Lokasi dan Partisipan Kegiatan}

Kegiatan pengabdian kepada masyarakat berlokasi di Desa Kota Agung, Kecamatan Sungkai Selatan, Kabupaten Lampung Utara. Partisipan kegiatan adalah masyarakat peternak kambing sebagai mitra kegiatan sebanyak 31 orang. Tahapan pelaksanaan kegiatan pengabdian kepada masyarakat disajikan pada Gambar 1.

\section{Bahan dan Alat}

Bahan yang digunakan pada kegiatan pengabdian ini adalah alkohol 70\%, Intermectin $\AA$, Intertrim LA $\AA$, Vetadryl $®$ Inj, Biosan $T P \AA$ Inj, Calcidex $\AA$ Plus, Sulfa Strong $\AA$, Gusanex $®$, Vitamin B kompleks, Vitamin B1, Alben-10®, Wormzole $\AA$, desinfektan, dan 232 ekor kambing milik masyarakat peternak. Peralatan pada kegiatan pengabdian ini adalah alat tulis, kuesioner pre-test, kuesioner post-test, modul penyuluhan manajemen kesehatan ternak kambing, modul penyuluhan manajemen reproduksi ternak kambing, modul manajemen sanitasi kandang ternak kambing, masker, glove latex disposable, spuit $5 \mathrm{~mL}$ disposable, spuit $1 \mathrm{~mL}$ disposable, kapas, alat penyemprot desinfektan/sprayer, dan sepatu boot.

\section{Metode Pelaksanaan Kegiatan}

Kegiatan pengabdian ini dilakukan dengan metode: 1) Penyuluhan meliputi kegiatan diskusi dan demonstrasi sesuai dengan topik yang diberikan (manajemen kesehatan, reproduksi, dan sanitasi kandang); 2) Pelaksanaan kegiatan sanitasi kandang ternak kambing; dan 3) Pemeriksaan kesehatan, pengobatan, pemeriksaan kebuntingan dan penanganan gangguan kesehatan, dan reproduksi ternak kambing secara massal.

\section{Pengumpulan data}

Pengumpulan data kegiatan pengabdian ini diukur dengan pemberian kuesioner yang diisi oleh masyarakat peternak kambing di Desa Kota 


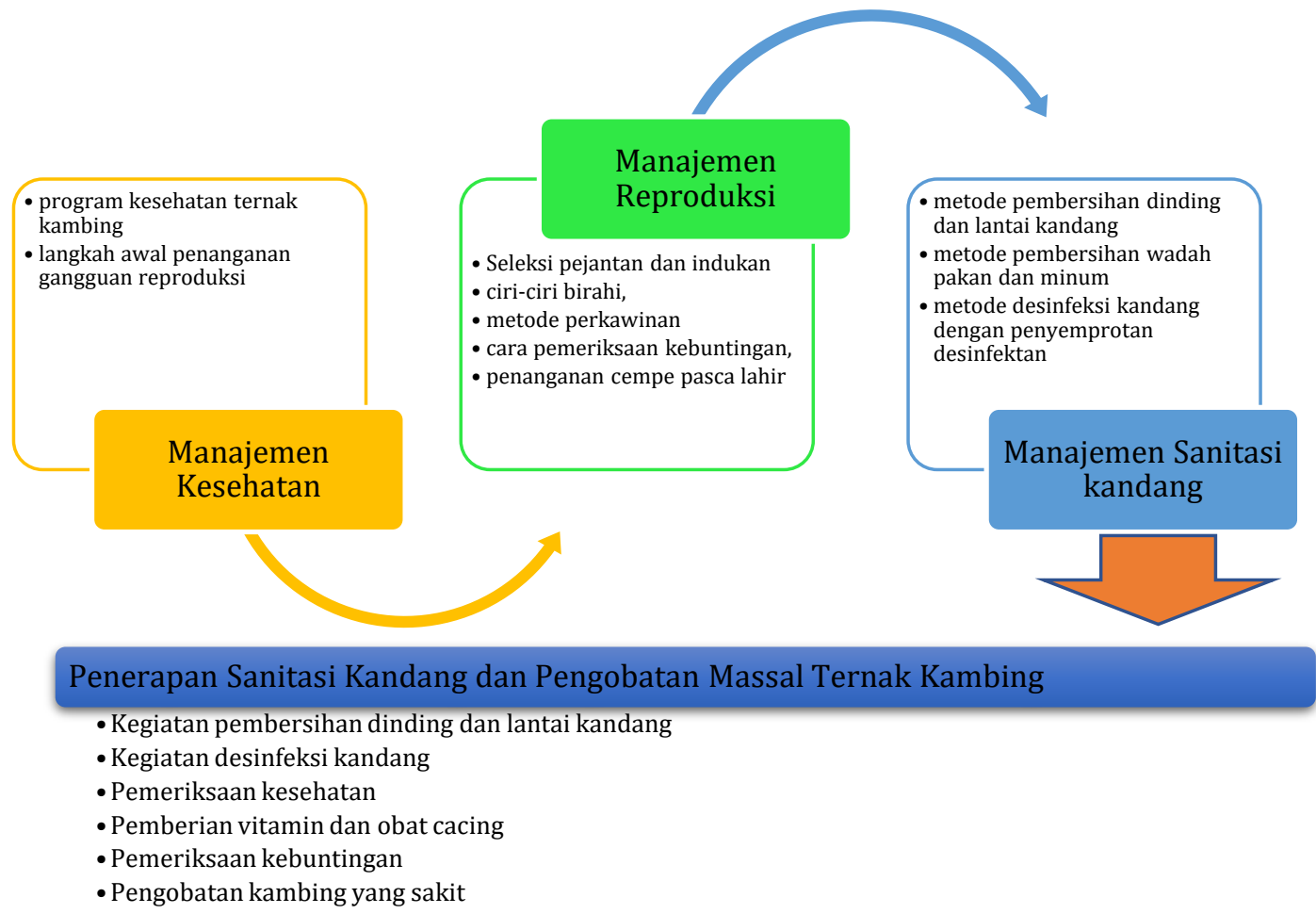

Gambar 1 Tahapan pelaksanaan kegiatan pengabdian kepada masyarakat.

Agung, Kecamatan Sungkai Selatan, Kabupaten Lampung Utara pada sebelum (pre-test) dan sesudah (post-test) kegiatan pengabdian dilakukan. Data yang diisi dalam kuesioner, yaitu data nama peternak, usia peternak, jenis kelamin peternak, dan jumlah kepemilikan kambing. Kuesioner berisi sebanyak 24 pertanyaan berbentuk pilihan ganda terkait penggalian data mengenai pengetahuan peternak terkait kesehatan, reproduksi, dan sanitasi kandang kambing.

\section{Pengolahan data}

Pengolahan data dilakukan dengan 1) Evaluasi awal (pre-test), evaluasi awal dilakukan dengan memberikan daftar pertanyaan kepada peserta (kuesioner) yang bertujuan untuk mengetahui tingkat pengetahuan peserta tentang manajemen kesehatan, reproduksi dan sanitasi kandang sebelum kegiatan dilaksanakan; 2) Evaluasi proses, evaluasi proses dilakukan dengan tujuan untuk mengetahui respon peserta terhadap materi yang disampaikan dalam pelaksanaan kegiatan ceramah. Evaluasi ini berupa diskusi interaktif dengan peserta dengan memberi kesempatan kepada mereka untuk melontarkan pertanyaanpertanyaan dan didiskusikan secara bersamasama; dan 3) Evaluasi akhir (post-test), evaluasi akhir dilakukan dengan mengajukan per- tanyaan berupa daftar pertanyaan (kuesioner) kepada para peserta, bertujuan untuk mengukur peningkatan pengetahuan peserta setelah kegiatan dilaksanakan.

\section{Analisis data}

Analisis data dilakukan dengan mengkategorikan tingkat pengetahuan peserta menjadi tiga kategori berdasarkan persentase hasil perhitungan kuesioner pre-test dan post-test, yaitu 1) Rendah dengan skor nilai $<50 \%$; 2) Sedang dengan skor nilai 50-70\%; dan 3) Tinggi dengan skor nilai $>70 \%$.

\section{HASIL DAN PEMBAHASAN}

\section{Survei}

Kegiatan pengabdian kepada masyarakat diawali dengan pelaksanaan survei pada tanggal 30 Januari 2020 (Gambar 2). Survei memiliki tujuan untuk mengidentifikasi tempat dan keadaan masyarakat sasaran, yang merupakan interaksi awal terhadap masyarakat calon mitra untuk mendapatkan data informasi serta kendala yang dihadapi oleh calon kelompok mitra. Survei dilaksanakan dengan metode diskusi dengan aparat desa untuk mengetahui permasalahan utama pada bidang peternakan yang sering terjadi di wilayah Desa Kota Agung, 


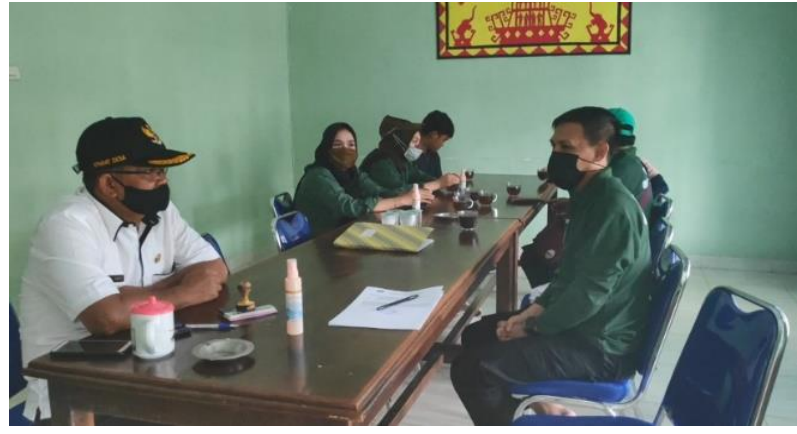

a

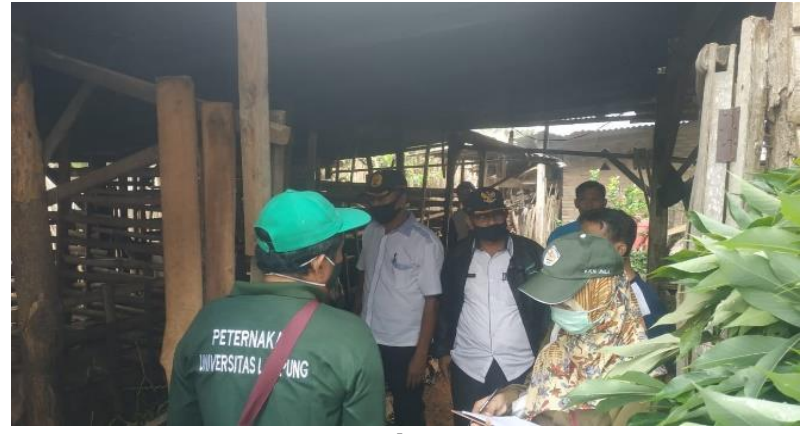

b

Gambar 2 a dan b Survei lokasi dan koordinasi dengan aparat desa terkait rencana pelaksanaan kegiatan pengabdian kepada masyarakat.

sehingga dapat menjadi bahan pertimbangan dalam menentukan lokasi pelaksanaan kegiatan. Selanjutnya dilakukan metode survei ke beberapa lokasi kelompok ternak berdasarkan saran dan pertimbangan dari kepala desa, sehingga penentuan lokasi kegiatan dapat dilakukan. Berdasarkan hasil survei dan koordinasi dengan aparat desa dan peternak, maka ditetapkan Desa Kota Agung menjadi lokasi pengabdian.

Hasil survei terhadap kondisi kandang (Gambar 3) sebagai berikut:

- Kondisi kandang tanpa atap monitor, yaitu tipe atap kandang yang terdiri dari dua sisi samping dengan keberadaan lubang angin pada bagian puncaknya, maka sirkulasi udara di dalam kandang sulit sehingga beresiko panas dan lembab, kandang yang lembab disukai oleh mikroorganisme patogen penyebab penyakit virus, bakteri, parasite, dan jamur.

- Tinggi kolong lantai tidak mencapai tinggi ideal $1 \mathrm{~m}$, sehingga membuat tumpukan feses sulit dibersihkan.

- Lantai kandang hanya dari tanah sehingga feses dan urin dapat bertumpuk membentuk gas amonia yang dapat membuat kambing kesulitan bernapas karena dampaknya yang membuat kerusakan pada paru-paru.

- Tumpukan feses pada kandang dapat membuat lalat berdatangan sehingga kambing akan terganggu kenyamanannya dan dapat mengakibatkan stress jika berlangsung dalam waktu lama.

- Upaya sanitasi kandang berupa pembersihan sudah dilakukan peternak tetapi belum rutin dilakukan, hal ini menyebabkan feses kambing bertumpuk di kandang dan dapat menimbulkan masalah kesehatan.

Berdasarkan hasil survei, diskusi dengan peternak, dan koordinasi dengan aparat desa

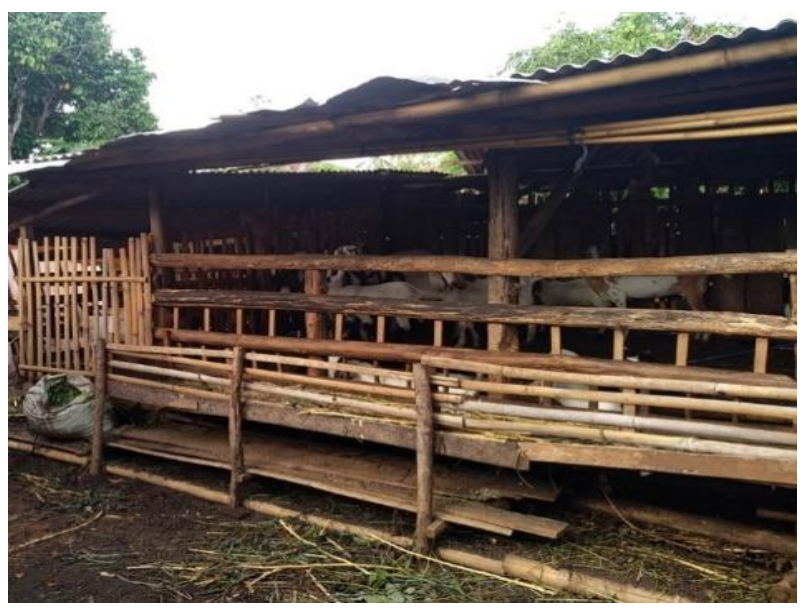

Gambar 3 Kondisi kandang kambing tanpa atap monitor, tinggi kolong tidak ideal, lantai kandang alas tanah, dan tumpukan feses di kendang.

untuk menggali masalah dalam pemeliharaan ternak kambing pada calon mitra kemudian bersama merumuskan solusi penyelesaian masalah (Tabel 1) melalui program PkM Dosen Pemula. Pemilihan masalah didasarkan pada prioritas dan nilai strategisnya di dalam menentukan keberhasilan program di kemudian hari, selanjutnya kegiatan survei ini juga menjadi sarana sosialisasi tentang kegiatan pengabdian yang akan dilaksanakan.

\section{Kegiatan Penyuluhan}

Penyuluhan atau diseminasi adalah proses transfer hasil kajian teknologi kepada masyarakat serta proses pembelajaran bagi pelaku utama serta pelaku usaha agar mau dan mampu menolong dan mengorganisasikan dirinya dalam meningkatkan produktivitas, efisiensi usaha, pendapatan dan kesejahteraan (Permentan No. 14/Permentan/OT.140/3/2011). Diseminasi ilmu pengetahuan dan inovasi teknologi pada peternak membutuhkan sosialisasi dalam bentuk 
Tabel 1 Solusi penyelesaian masalah berdasarkan hasil survei

\begin{tabular}{|c|c|}
\hline Situasi sekarang & Solusi \\
\hline $\begin{array}{l}\text { Peternak belum mengetahui, } \\
\text { memahami pentingnya program } \\
\text { kesehatan kelompok ternak } \\
\text { kambing serta langkah awal pe- } \\
\text { nanganan jika terjadi gangguan } \\
\text { kesehatan. }\end{array}$ & $\begin{array}{l}\text { Penyuluhan, diskusi, } \\
\text { dan pemeriksaan kesehatan, } \\
\text { pengobatan ternak kambing } \\
\text { yang sakit serta penang- } \\
\text { gulangan jika terjadi } \\
\text { gangguan kesehatan. }\end{array}$ \\
\hline
\end{tabular}

Peternak belum mengetahui dan memahami manajemen reproduksi ternak kambing yang baik dan benar secara intensif
Penyuluhan, diskusi, dan pemeriksaan reproduksi ternak kambing
Peternak belum mengetahui, memahami program sanitasi kandang yang sesuai dengan kondisi iklim dan geografis setempat yang memenuhi aspek sanitasi dan higienitas.

Peternak belum mengetahui dan memahami arti penting koordinasi dalam anggota kelompok ternak untuk membuat jadwal pengobatan massal ternak kambing dan pemberian obat cacing dan vitamin secara rutin
Penyuluhan, diskusi, dan inspeksi mengenai gambaran iklim dan geografis, struktur kandang dan lingkungan di sekitar kandang.

Penyuluhan, diskusi, dan membuat jadwal serta pelaksanaan pengobatan massal ternak kambing
Peternak mengetahui,

memahami dan mampu melaksanakan mengetahui dan memahami arti penting program kesehatan ternak kambing melalui pemeriksaan kesehatan dan pengobatan dini pada kambing yang sakit serta langkah awal penanganan jika terjadi gangguan kesehatan.

Peternak mengetahui dan memahami segala aspek mengenai manajemen reproduksi ternak kambing yang baik dan benar melalui pemahaman mengenai pemilihan pejantan dan indukan, ciri-ciri birahi, metode perkawinan alami atau kawin suntik, pemeriksaan kebuntingan, serta penanganan anak kambing (cempe) setelah lahir.

Peternak dapat membuat perencanaan program sanitasi kandang yang sesuai dengan kondisi iklim dan geografis setempat yang memenuhi aspek sanitasi dan higienitas untuk menunjang kesehatan dan reproduksi ternak kambing.

\section{Peternak mengetahui dan}

memahami pentingnya perencanaan jadwal pengobatan dengan vitamin dan obat cacing secara rutin serta dapat membuat jadwal pengobatan rutin di kelompok ternak. penyuluhan dan berbagai media informasi sebagai pendukung kegiatan penyuluhan.

Keberhasilan kegiatan penyuluhan ditentukan oleh unsur seperti penyuluh, informasi, peternak, penggunaan media, dan metode penyuluhannya. Metode penyuluhan dapat memengaruhi tingkat keberhasilan penyerapan informasi, seperti kunjungan ke kandang, demontrasi seperti pengobatan ternak dan sanitasi kandang dan kampanye atau model diskusi merupakan jenis metode penyuluhan yang relevan dengan kondisi peternak dan mudah untuk diterapkan. Kesesuaian antara metode dengan kondisi peternak sasaran akan dapat mempercepat terjadinya proses adopsi teknologi informasi, sehingga berdampak positif terhadap usaha peternakan yang dilakukan (Ediset \& Jaswandi 2017).

Kegiatan penyuluhan dan diskusi (Gambar 4) dengan anggota kelompok ternak serta pengisian kuosioner oleh para peternak sebelum (pre-test) kegiatan dan setelah (post-test) kegiatan sehingga dapat diketahui permasalahan utama dalam manajemen kesehatan dan reproduksi, penanganan gangguan kesehatan serta pentingnya kegiatan sanitasi kandang untuk menjaga kandang bebas dari penyakit yang dapat menyerang ternak yang dipelihara. Sebanyak 31 orang peternak hadir dalam kegiatan penyuluhan. Kegiatan penyuluhan dimulai pada pukul 10.0012.00 WIB. Kegiatan penyuluhan dibuka dengan sambutan dari Sekretaris Desa Kota Agung kemudian dilanjutkan dengan sesi penyajian materi oleh tim pengabdian. Materi yang diberikan mengenai 1) Manajemen kesehatan sehingga peternak mengetahui, memahami pentingnya program kesehatan kelompok ternak kambing serta langkah awal penanganan jika terjadi gangguan kesehatan; 2) Manajemen reproduksi sehingga peternak mengetahui dan memahami segala aspek mengenai pemilihan 


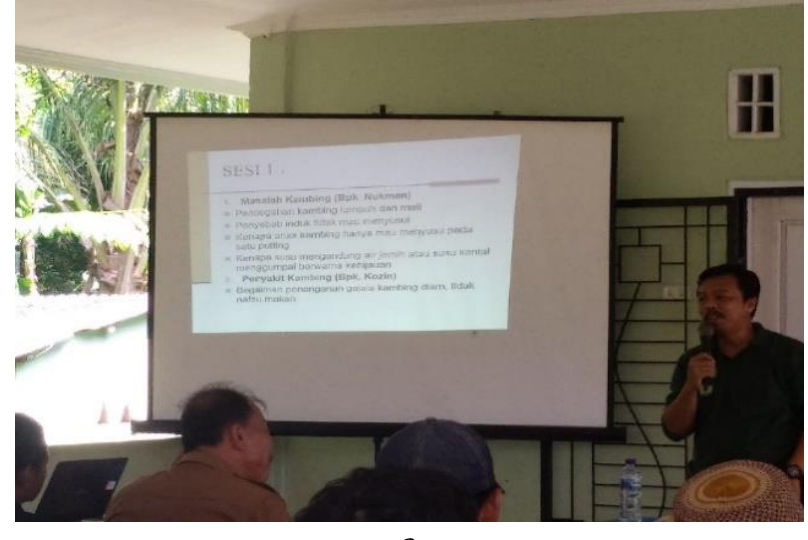

a

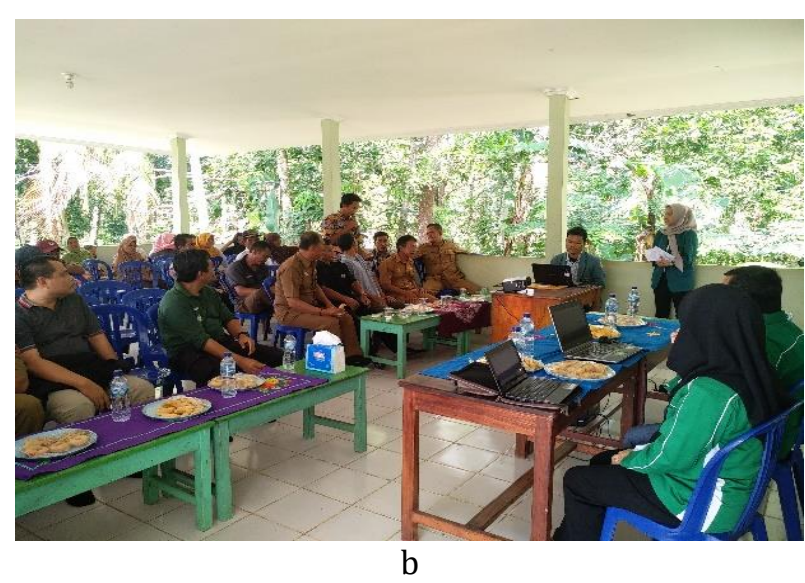

Gambar 4 a dan b Kondisi pelaksanaan kegiatan penyuluhan.

pejantan dan indukan, ciri-ciri birahi, metode perkawinan alami atau kawin suntik, pemeriksaan kebuntingan, serta penanganan anak kambing (cempe) setelah lahir; dan 3) Manajemen sanitasi kandang sehingga peternak mampu membuat perencanaan program sanitasi kandang yang memenuhi aspek sanitasi dan higienitas untuk menunjang kesehatan dan reproduksi ternak kambing. Kegiatan penyuluhan diakhiri dengan sesi tanya jawab dan diskusi.

Tim pengabdian melakukan kegiatan penyuluhan dengan cara menyampaikan materi penyuluhan melalui berbagai forum komunikasi seperti temu lapang di rumah ketua kelompok ternak, urun rembug dengan peternak dengan metode diskusi dan kaji terap atau temu teknis, yaitu pengobatan dan sanitasi kandang kambing (Sejati \& Indraningsih 2015) dengan melibatkan peran aktif peternak. Kegiatan pengabdian kepada masyarakat dalam bentuk penyuluhan memiliki peran sangat besar dalam meningkatkan pendapatan anggota kelompok peternak (Asfar 2016).

Tingkat pengetahuan peternak sebelum dan setelah kegiatan dilaksanakan disajikan pada Gambar 5. Berdasarkan data yang diperoleh dari data kuesioner yang diisi oleh anggota kelompok ternak kemudian dilakukan pengolahan data, dapat dilihat bahwa tingkat pengetahuan peternak mengenai manajemen reproduksi dan kesehatan dalam pemeliharaan kambing meningkat signifikan.

\section{- Penyuluhan manajemen kesehatan ternak kambing}

Tingkat pengetahuan peternak sebelum kegiatan dilaksanakan pada sisi pengetahuan kesehatan ternak kambing sebelum kegiatan sebesar $28,24 \%$ meningkat menjadi $82,26 \%$ setelah kegiatan penyuluhan dilaksanakan. Menurut Widyastuti et al. (2017) bahwa faktor penghambat yang menyebabkan rendahnya produktivitas kambing adalah minimnya pengetahuan peternak tentang manajemen kesehatan ternak, sehingga hal ini dapat meimbulkan berbagai penyakit pada ternak dan mengakibatkan kerugian ekonomi seperti penurunan produksi, gangguan reproduksi, peningkatan biaya pengobatan, hingga kematian. Pe ternak terkadang tidak mengetahui bahaya penyakit dan cara pecegahannya. Pengetahuan mengenai penyakit pada kambing seperti gejala klinis sehingga dapat menggali informasi sejarah penyakit, pengamatan, dan pemeriksaan fisik kambing akan sangat membantu peternak mencegah kambing terserang penyakit.

Program kesehatan kelompok ternak (PKKT) yang dapat diterapkan menurut Santosa (2017) adalah serangkaian kegiatan untuk menjaga kondisi kesehatan ternak secara terpadu pada peternakan terkait ternak dan faktor-faktor yang berpengruh terhadap kesehatan agar usaha peternakan dapat terlaksana secara serasi dan tujuan beternak sesuai prinsip ekonomi berjalan optimal. Program PKKT adalah 1) Vaksinasi atau pemberian vaksin sehingga kebal terhadap penyakit; 2) Biosekuriti meliputi sanitasi dan desinfeksi kandang dan peralatan kandang; 3) Pemberantasan endoparasit dan ektoparasit; 4) Penanganan gangguan reproduksi; dan 5) Recording atau administrasi kesehatan ternak.

\section{- Penyuluhan manajemen reproduksi ternak kambing}

Tingkat pengetahuan peternak sebelum kegiatan dilaksanakan pada sisi pengetahuan reproduksi ternak kambing sebesar 51,94\% meningkat menjadi $78,71 \%$ setelah kegiatan penyuluhan dilaksanakan. Salah satu kendala 


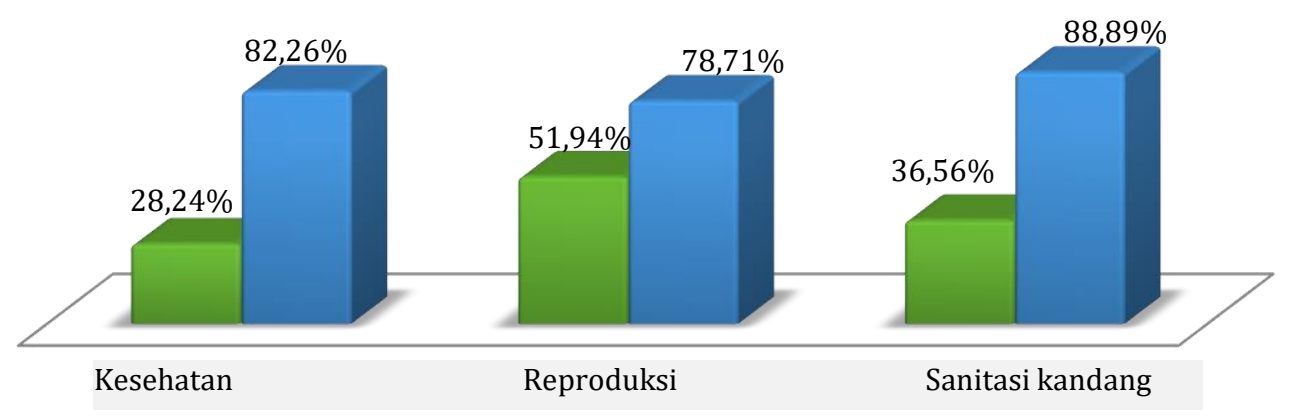

Gambar 5 Hasil pre-test dan post-test pelaksanaan kegiatan.

yang dihadapi oleh peternak ruminansia dalam mengembangkan usahanya adalah masalah reproduksi dikarenakan produktivitas rendah, sehingga menyebabkan populasi ternak tidak bertambah. Reproduksi ternak adalah proses fisiologis ternak menghasilkan keturunan. Berdasarkan pernyataan Kurniasih et al. (2013) terdapat faktor-faktor yang berpengaruh terhadap reproduksi ternak, yaitu perkawinan, penanganan anak yang baru lahir, ketersediaan, dan kualitas pakan serta penanganan kesehatan kambing. Perkawinan harus dilakukan secara terencana dan tepat waktu serta kondisi ternak baik dan sehat. Perkawinan dapat dilakukan dengan dua cara, yaitu perkawinan alami dan buatan. Perkawinan dilakukan jika ternak sudah dewasa tubuh dan menunjukkan tanda-tanda birahi. Dewasa tubuh adalah keadaan dimana betina siap bunting dan melahirkan anak sedangkan pada jantan dewasa ditunjukkan dengan umur di atas 1 tahun.

Menurut Sukendar et al. (2005) bahwa potensi pengembangan kambing di daerah pedesaan perlu diketahui dengan tujuan memperkirakan pertambahan populasi kambing persatuan waktu, agar informasi angka populasi dan program pengembangan kambing selanjutnya dapat diketahui. Untuk meningkatkan angka populasi kambing dibutuhkan manajemen perkawinan, umur kawin ternak betina perlu diatur sehingga produktivitas dapat terjaga, yaitu dengan mengawinkan kambing betina yang sudah dewasa kelamin. Tujuan dilakukan agar segera setelah perkawinan tingkat kebuntingan kambing optimum (Kurniasih et al. 2013) karena waktu kawin yang kurang tepat dapat berdampak terhadap kegagalan bunting (Budi 2005).

\section{- Penyuluhan manajemen sanitasi kandang ternak kambing}

Tingkat pengetahuan peternak sebelum kegiatan dilaksanakan pada sisi pengetahuan sanitasi kandang kambing sebelum kegiatan sebesar 36,56\% meningkat menjadi $88,89 \%$ setelah kegiatan dilaksanakan. Sanitasi kandang merupakan sebuah program kebersihan kandang yang bertujuan untuk mencegah masuk dan perpindahan bibit penyakit maupun parasit yang menyerang ternak menggunakan desinfektan pada dosis yang dianjurkan, sehingga kandang tergolong dalam kandang sehat. Kriteria kandang kambing dan domba yang sehat menurut Hidayat et al. (2015) adalah 1) Memenuhi aspek teknis kandang seperti letak, ukuran, lantai, bentuk, sirkulasi udara, fasilitas kandang, bahan kandang, atap, dan dinding; 2) Lingkungan kandang mencakup drainase, instalasi limbah, tempat gembala, kebersihan, dan sumber air; 3) Kambing memiliki kebersihan bulu, mata, moncong, kuku, telinga, dan anus; dan 4) Kondisi peternak dan keluarga dalam kondisi sehat. Tujuan sanitasi kandang untuk mematikan penyakit di dalam kandang secara menyeluruh mencakup kandang, lingkungan di sekitar kandang, dan peralatan kandang. Pembersihan kandang sebaiknya dilakukan dua kali sehari pada pagi dan sore hari (BPTP Maluku 2019).

Sanitasi kandang adalah kegiatan pencegahan termasuk kebersihan bangunan tempat tinggal ternak atau kandang dan lingkungannya dalam rangka untuk menjaga kesehatan ternak sekaligus pemiliknya. Hal-hal yang dapat berpengaruh terhadap sanitasi kandang, yaitu konstruksi bangunan kandang, lokasi kandang, kebersihan kandang, dan kepadatan parasit. Lokasi kandang seharusnya terpisah dengan 
rumah dengan jarak minimal $10 \mathrm{~m}$, ketersediaan air bersih yang cukup dan terdapat lokasi penampungan kotoran atau sisa pakan ternak (BPTP Ungaran 2000) serta kemiringan pada lantai diperlukan untuk memudahkan peternak dalam melakukan proses pembersihan kandang dan menjaga lantai kandang supaya tetap kering (Maulida 2013). Lokasi kandang dengan sanitasi yang buruk dan keberadaan genangan air juga dapat memungkinkan ternak menderita cacingan seperti cacing hati Fasciola sp. dan cacing saluran pencernaan, maka infestasi cacing ini dapat menurunkan nilai total eritrosit dan esosinofilia sehingga menyebabkan anemia pada ternak (Barkah et al. 2021; Siswanto et al. 2018; Hartono et al. 2019).

\section{Kegiatan Sanitasi Kandang}

Kegiatan sanitasi kandang dilakuakn pada 31 unit kandang milik peternak (Gambar 6) serta bantuan peralatan sanitasi kadang berupa 10 unit sprayer kapasitas 2 L dan 10 botol desinfektan diberikan melalui aparat desa. Kegiatan sanitasi kandang dilakukan dengan 1) Membersihkan kandang terlebih dahulu dari kotoran dengan cara menyapu lantai kandang dengan sapu lidi; 2) Penyemprot lantai dengan air dan sisi kandang; 3) Pembuatan larutan desinfektan dengan cara mencampurkan obat desinfektan sebanyak $5 \mathrm{~mL}$ ditambah air sebanyak 2 L di dalam unit sprayer; dan 4) Melakukan desinfeksi kandang dengan menyemprotkan larutan desinfektan menggunakan sprayer pada bangunan kandang.

Kondisi kandang milik peternak di Desa Kota Agung pada umumnya dengan kontruksi kandang tanpa atap monitor yang akan mempengaruhi minimnya sirkulasi udara di dalam kandang. Kondisi tersebut beresiko panas dan lembab, kandang yang lembab disukai oleh mikroorganisme patogen penyebab penyakit virus, bakteri, parasite, dan jamur. Agus et al. (2014) menyatakan bahwa feses mengandung mikroorganisme seperti E. coli dan Salmonella sp. yang dapat menyebabkan gangguan kesehatan pada manusia. Menurut Haryanto \& Thalib (2009) kotoran sapi juga mengandung gas metana (CH4) yang cukup tinggi yaitu sekitar 2$15 \%$ dari total energi yang dimakan ternak.

Bangunan kandang kambing yang dimiliki para peternak di Desa Kota Agung memiliki tinggi kolong lantai terlalu pendek sehingga sulit membersihkan feses, kondisi lantai masih tanah sehingga masih menyisakan feses dan urin setelah dibersihkan. Tumpukan feses pada kan-

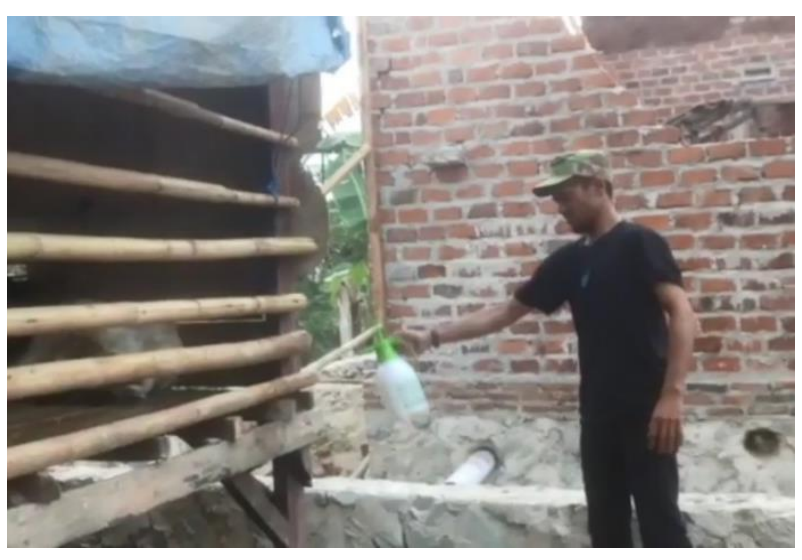

Gambar 6 Kegiatan sanitasi kandang kambing milik peternak.

dang dapat membuat lalat berdatangan, sehingga kambing akan terganggu kenyamanannya dan dapat mengakibatkan stress jika berlangsung dalam waktu lama. Upaya sanitasi kandang berupa pembersihan sudah dilakukan peternak tetapi belum rutin dilakukan sehingga dapat menimbulkan masalah kesehatan. Kegiatan yang disarankan oleh tim pengabdian kepada masyarakat kepada peternak sesuai pendapat Bulan dan Subekti (2018) adalah menampung feses dan urine, mengolah bahan feses dan urine kambing menjadi pupuk organik cair, menggali potensi manfaat pupuk organik cair menjadi insektisida dan pestisida organik, memasarkan hasil produk olahan pupuk organik padat, pupuk organik cair, dan pestisida organik cair.

\section{Kegiatan Pengobatan Massal Ternak Kambing \\ Pengobatan massal kambing dilakukan pada} 232 ekor kambing yang dipelihara oleh para peternak. Kegiatan pengobatan massal ternak kambing (Gambar 7) terdiri dari pemeriksaan kesehatan kambing sebanyak 232 ekor, pemeriksaan kebuntingan sebanyak 115 ekor, penanganan gangguan reproduksi sebanyak 1 ekor, pemberian vitamin sebanyak 232 ekor dan pemberian obat cacing sebanyak 21 ekor serta pengobatan pada ternak kambing yang terdiagnosa menderita penyakit sebanyak 3 ekor. Kegiatan dilakukan pada pukul 13.30-16.30 WIB di dua Dusun di Desa Kota Agung. Kegiatan pengobatan dilakukan oleh tim pengabdian dan dibantu oleh 1 orang dokter hewan dari Persatuan Dokter Hewan Indonesia Cabang Lampung dan 3 orang tenaga paramedis veteriner dari Dinas Pertanian Kabupaten Lampung Utara.

\section{Keberhasilan Kegiatan}

Keseluruhan proses kegiatan pengabdian 


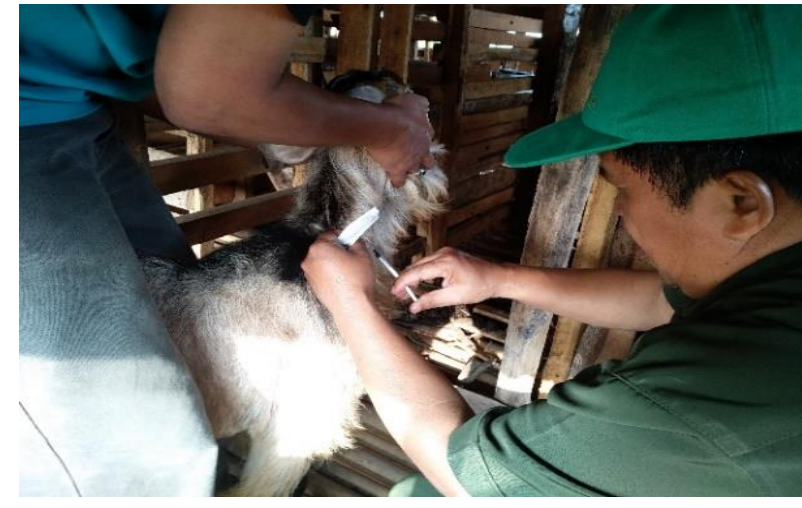

a

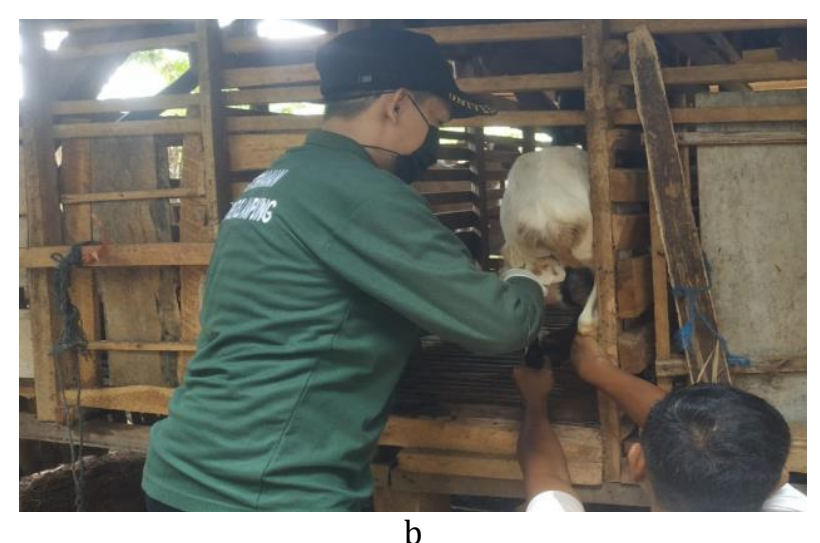

b

Gambar 7 Pelaksanaan pemeriksaan kesehatan dan pengobatan massal kambing milik peternak.

kepada masyarakat tidak terdapat kendala yang dihadapi oleh tim. Hal ini dikarenakan koordinasi yang intensif dilakukan oleh tim terhadap pihak-pihak yang bekerja sama dalam kegiatan ini dan turut memberikan kontribusi besar terhadap kegiatan mulai dari tahap survei lokasi pelaksanaan hingga rangkaian kegiatan pengabdian terlaksana. Berbagai pihak yang berkontribusi terhadap keberlangsungan kegiatan sebagai berikut.

- Aparat Desa Kota Agung, Kecamatan Sungkai Selatan, Kabupaten Lampung Utara yang berkontribusi sebagai pemangku wewenang izin lokasi pelaksanaan kegiatan dan pengkondisian masyarakat sebagai partisipan kegiatan;

- Tenaga paramedis veteriner dari Dinas Pertanian Kabupaten Lampung Utara yang berkontribusi pada bantuan tenaga pengobatan massal dan sanitasi kandang serta obatobatan;

- Peternak kambing Desa Kota Agung, Kecamatan Sungkai Selatan, Kabupaten Lampung Utara sebagai mitra kegiatan yang berkontribusi pada persiapan lokasi kegiatan, pengumpulan peserta dan pengkondisian ternak di tiap unit kandang;

- Persatuan Dokter Hewan Indonesia (PDHI) Cabang Provinsi Lampung yang berkontribusi dalam bantuan tenaga dokter hewan dan obatobatan pada saat pengobatan massal ternak kambing;

- Ikatan Sarjana Peternakan Indonesia (ISPI) Cabang Provinsi Lampung yang berkontribusi dalam bantuan edukasi dan transfer ilmu pengetahuan kepada peternak mengenai tatalaksana sanitasi kandang kambing.

- Mahasiswa Jurusan Peternakan, Fakultas Pertanian, Universitas Lampung sebanyak empat mahasiswa yang berkontribusi tenaga pada tiap rangkaian kegiatan pengabdian.

\section{Pelaksanaan}

Kegiatan yang dilakukan oleh tim pengabdian kepada masyarakat memberikan hasil positif berupa 1) Peningkatan pengetahuan dan pemahaman terkait manajemen kesehatan, reproduksi dan sanitasi kandang; 2) Terlaksananya kegiatan pemeriksaan kesehatan, pemeriksaan kebuntingan, pengobatan sesuai dengan kondisi klinis yang tampak, pemberian vitamin, dan obat cacing terhadap kambing milik peternak; dan 3) Terlaksananya kegiatan sanitasi kandang pada 31 unit kandang milik peternak serta bantuan peralatan sanitasi kadang berupa 10 unit sprayer dan 10 botol desinfektan yang diberikan melalui aparat desa.

\section{Upaya Keberlanjutan Kegiatan}

Upaya berkelanjutan yang dilakukan oleh tim pengabdian kepada masyarakat adalah tetap menjalin komunikasi dengan berbagai pihak yang telah berkontribusi terutama pada mitra kegiatan, yaitu masyarakat peternak kambing di Desa Kota Agung, Kecamatan Sungkai Selatan, Kabupaten Lampung Utara sehingga proses transfer ilmu pengetahuan terkait manajemen kesehatan, reproduksi, dan sanitasi kandang yang telah diterima dapat diaplikasikan secara berkelanjutan.

\section{SIMPULAN}

Kegiatan pengabdian masyarakat memberikan manfaat yang luar biasa terhadap peningkatan pengetahuan dan kemampuan peternak pada sisi pengetahuan kesehatan ternak kambing sebesar 54,02\%; pada sisi reproduksi sebesar 26,77\%; dan pada sisi pengetahuan sanitasi kandang kambing sebesar 52,33\%. Keberlangsungan program dapat dijaga dengan 
cara aparat desa beserta masyarakat peternak kambing meningkatkan komunikasi dengan berbagai pihak yang membidangi peternakan dan kesehatan hewan agar dapat meningkatkan intensitas penyuluhan dan pelatihan terkait budi daya ternak kambing, manajemen pemeliharaan terkait kesehatan, reproduksi, sanitasi kandang, serta fermentasi limbah ubi kayu yang memiliki potensi besar pengembangan alternatif pakan ternak kambing di Desa Kota Agung, Kecamatan Sungkai Selatan, Kabupaten Lampung Utara, Provinsi Lampung.

\section{UCAPAN TERIMA KASIH}

Penulis mengucapkan terima kasih kepada Universitas Lampung yang telah memberikan pembiayaan kegiatan Pengabdian Kepada Masyarakat Skema Dosen Pemula yang bersumber dari dana DIPA BLU Universitas Lampung T.A. 2020. Kami juga mengucapkan terima kasih kepada Dinas Pertanian Kabupaten Lampung Utara atas bantuan tenaga medis dan obat hewan.

\section{DAFTAR PUSTAKA}

Agus C, Faridah E, Wulandari D, Purwanto BH. 2014. Peran Mikroba Starter dalam Dekomposisi Kotoran Ternak dan Perbaikan Kualitas Pupuk Kandang. Jurnal Manusia dan Lingkungan. 21(2): 179-187.

Asfar I. 2016. Peranan Penyuluh Peternakan dalam Peningkatan Pendapatan Anggota Kelompok Peternak Sapi Potong di Kabupaten Sinjai (Studi Kasus: Desa Patallassang Kecamatan Sinjai Timur). [Skripsi]. Makassar (ID): Universitas Islam Negeri Alauddin.

[BPTP] Balai Pengkajian Teknologi Pertanian aluku. 2019. Sanitasi pada Ternak Ruminansia dan Manfaatnya. [Internet]. [diunduh 28 September 2020]. Tersedia pada: http:// maluku.litbang.pertanian.go.id/?p=2668.

[BPTP] Balai Pengkajian Teknologi Pertanian Ungaran. 2000. Sanitasi Kandang Sapi Perah. Jawa Tengah (ID): BPTP Ungaran.

Barkah A, Hartono M, Santosa PE, Sirat MMP. Tingkat Infestasi Cacing Saluran Pencernaan pada Kerbau Lumpur (Bubalus bubalis Linn.) di Kecamatan Jati Agung Kabupaten Lampung
Selatan. Jurnal Ilmiah Peternakan Terpadu. 9(1): Juli 2021.

Budi U. 2005. Pengaruh interval pemerahan terhadap aktivitas seksual setelah beranak pada kambing Peranakan Etawah. Jurnal Agribisnis Peternakan. 1(2): 53-61.

Bulan DS, Subekti S. 2018. Proses Pembelajaran Sosial Perkandangan Pada Peternak Kambing. Dalam: Seminar Nasional Program Studi Agribisnis Fakultas Pertanian Universitas Jember. Universitas Jember, Jember (ID). 3 November 2018.

Ediset, Jaswandi. 2017. Metode Penyuluhan dalam Adopsi Inovasi Inseminasi Buatan (IB) pada Usaha Peternakan Sapi di Kabupaten Dharmasraya. Jurnal Peternakan. 14(1): 1-10. https://doi.org/10.24014/jupet.v14i1.3395

Hartono M, Elisa, Siswanto, Suharyati S, Santosa PE, Sirat MMP. 2019. Profil darah pada Sapi Simmental-Peranakan Ongole akibat infestasi cacing trematoda di Desa Labuhan Ratu, Kecamatan Labuhan Ratu, Kabupaten Lampung Timur, Provinsi Lampung. Dalam: Prosiding Seminar Nasional Teknologi Peternakan dan Veteriner 2019. Pusat Penelitian dan Pengembangan Peternakan, Bogor (ID). 15-16 Oktober 2019.

Haryanto B, Thalib A. 2009. Emisi Metana dari Fermentasi Enterik: Kontribusinya Secara Nasional dan Faktor-Faktor yang Memengaruhinya pada Ternak. Wartazoa. 19(4): 157-165.

Hidayat R, Santoso K, Suryahadi, Darwati S, Suprayogi A, Prastowo. 2015. Penilaian Kandang Sehat dan Produktif Domba di Desa/Kelurahan Lingkar Kampus Institut Pertanian Bogor, Darmaga. Agrokreatif Jurnal Ilmiah Pengabdian kepada Masyarakat. 1(1): 20-27. https://doi.org/10.29244/agrokreatif. 1.1.20-27

Kurniasih NN, Fuah AM, Priyanto R. 2013. Karakteristik reproduksi dan perkembanga populasi kambing peranakan etawah di lahan pascagalian pasir. Jurnal Ilmu Produksi dan Teknologi Peternakan. 1(3): 132-137.

Maulida FN. 2013. Tatalaksana Kesehatan Peternakan Sapi Perah Rakyat di Kecamatan Cisarua Kabupaten Bogor. [Skripsi]. Bogor (ID): Institut Pertanian Bogor. 
[Kementan] Kementerian Lingkungan Hidup. 2011. Peraturan Menteri Pertanian Nomor. 14/Permentan/OT.140/3/2011.

Santosa PE. 2017. Modul Program Kesehatan Kelompok Ternak. Bandar Lampung (ID): Universitas Lampung.

Sejati WK, Indraningsih KS. 2015. Implementasi Diseminasi Inovasi Pertanian dalam Perspektif Penyuluh. Dalam: Prosiding Seminar Nasional Perlindungan dan Pemberdayan Pertanian dalam Rangka Pencapaian Kemandirian Pangan Nasional dan Peningkatan Kesejahteraan Petani. IAARD Press, Bogor (ID). 10 November 2015.

Siswanto, Hartono M, Santosa PE, Suharyati S, Larasati H, Sirat MMP. 2018. Prevalensi Cacing
Hati Sapi Perah pada Peternakan Rakyat di Provinsi Lampung. Jurnal Ilmiah Peternakan Terpadu. 6(3): 167-172. https://doi.org/10. 23960/jipt.v6i3.p167-172

Sukendar A, Duldjaman M, Sukmawati A. 2005. Potensi reproduksi dan distribusi dalam pengembangan kambing PE di Desa Hegarmanah Kecamatan Cicantayan Kabupaten Sukabumi Jawa Barat. Media Peternakan. 28(1): 1-7

Widyastuti R, Winangun K, Wira DW, Ghozali M, Rizky M, Syamsunarno. 2017. Tingkat Pengetahuan Dan Respons Peternak Kambing Perah Terhadap Penyakit Hewan (Studi Kasus: Kelompok Tani "Simpay Tampomas" Cimalaka, Sumedang). Dharmakarya. 6(2): 89-92. 